\title{
The Effect of Exercise Behavior Change Processes in the Prevention of Obesity in Elderly
}

\author{
Pervin TOPTAȘ DEMİRCi* \\ Erdemli Department of Tourism Animation, Mersin University, Turkey \\ *Corresponding author: pervindemirci36@ hotmail.com
}

\section{Abstract}

This of study aim evaluate the effect of exercise behavior change processes on weight control in the prevention of obesity in elderly. This study was performed at age of 65 and over; formed a total of 25 participants who regularly try to improve their physical activity levels. Participants were selected from obesity levels (BMI $(\mathrm{kg} / \mathrm{m} 2) \geq 30.00)$ according to body mass index. Attitudes of the participants in the behavioral dimension were determined by the Exercise Change Process Scale (ECPS) before and 6 months after the intervention. All statistical analyzes were performed with SPSS version 20.0. P values of less than 0.05 were considered significant. Differences between control and intervention groups pretest and posttest were analyzed by $\mathrm{T}$ test. According to the findings, when the comparison of age, height, body weight and body mass index values of the control group, no significant difference was found between the pretest and posttest measurements $(p>0.05)$. However, there were significant decreases between the pretest and posttest measurements of the intervention group body weight and body mass index values $(\mathrm{p}<0.001)$. While there was an increase in the level of consciousness $(\mathrm{p}<0.05)$ according to the pretest and posttest results of the exercise group sub-dimensions of control group, no significant difference was found in other subdimensions and total score. However, there were significant differences in the other subscales and total scores $(\mathrm{p}<0.05)$ and $(\mathrm{p}<0.001)$ except for the helper sub-dimensions of the intervention group exercise change processes scale. In conclusion, prevention of obesity in the elderly The development of health within the scope of ECPS aims to make people sufficient to correct and control their own health.

\section{Keywords}

Aging, Obesity, Physical Activity, Behavior Change

\section{INTRODUCTION}

Overweightness and obesity have become widespread whose prevalence is increasing in most countries throughout the world. Obesity can be a cause of chronic illness or even death and is observed in both rich communities and in and in those characterized by low or moderate incomes (Obara-Gołebiowska et al., 2018; Potes et al., 2017). One of the most important causes of obesity, unbalanced nutrition and activity deficiency is the second most common cause of preventable deaths in the world (WHO, 2016). Due to the physiological changes in the organism the frequency of obesity is proportionally greater among older people. The increasing prevalence of overweight and obesity in elderly is especially associated with many psychophysical health problems and increased mortality. Therefore there is a need to apply various Physical Activity (PA) and exercise interventions to reduce the high prevalence of overweight and obesity among elderly population so that they can lead a socially secure life (Demirci and Toptaş Demirci, 2018; Yu ve ark., 2012; Lee and Mattson 2014).

Aging is associated with a decrease in many body functions; A change in structure is accompanied by a loss of lean mass and a relative increase in fat mass over time. Previously, these 
changes were thought to be inherent by age, but research over the past few decades have associated them with aging, low physical activity / immobility and not using degenerative diseases. These changes affect nutrient and food intake, nutritional preferences and diet patterns of the elderly (Shaheenet al., 2016). PA and exercise behavior change processes are useful in increasing the health and well-being of the elderly, helping to reduce the likelihood of obesity and delaying the decline in functional abilities and at the onset of chronic disease. It can reduce the severity of chronic illness-related disability, improve mental health, promote socialization, prolong independent life span, and even reduce the risk of falling (Myint, 2009; Hedley et al., 2004)

The physical activity and exercise process are considered to be an integral part of the lifting of the potential burden of an aging population not only by disease prevention, but more importantly by the removal of physiological reserve capacity or condition. Regular PA allows older adults to maintain many daily life jobs, even in disease and / or disability, required for independent function at older ages. However, with aging, older adults tend to become more immobile. The compound effect of chronic disease with age-related physiological deterioration is seen in the basic activities of daily life. Increased immobility may be due to the lack of information about the benefits and importance of physical activity and daily exercise in maintaining functional independence in old age (Obara-Gołebiowska ve ark., 2018; Miçooğulları , 2010).

In obesity, eating behavior is important in gaining healthy lifestyle behaviors such as changing nutrition and activity habits. Therefore, targets in obesity: Providing weight loss, protection of the reached weight, It is the use of regulatory mechanisms against obesity and preventing repetitions (Demirci et al., 2017; Kalantari et al., 2017). Transtheoretical Model (TM) describes the sequential behavior change in a person from an unhealthy behavior to a healthy behavior. 'New' is a deliberate change model that predicts the possible consequences of the behavior acquired during the adaptation process (Mastellos, 2014). In these studies, it is suggested that TM is a guide model with a change in behavior, theoretical framework dimension in the content, application and evaluation of nutrition and exercise-physical activity interventions for obesity patients. (Johnson et al., 2008; Redding et al., 2000). The aim of this study is to evaluate the weight control due to changes in exercise behavior change processes by using the Transtheoretical Model in the prevention of obesity in the elderly.

\section{MATERIALS AND METHODS}

\section{Participants}

Before starting the research, the rules to be followed were explained to the individuals in detail and the informed consent was signed. The necessary legal permits were obtained in the study. This study consisted of 25 obese participants with age of 65 years and over who were trying to improve their physical activity levels as regularly. The study was conducted in accordance with the Helsinki declaration (33).

\section{Procedures}

Participants were selected from obesity levels (BMI $\left.\left(\mathrm{kg} / \mathrm{m}^{2}\right) \geq 30\right)$ according to body mass index. Attitudes of the participants in the behavioral dimension were determined by the Exercise Change Process Scale (ECPS) before and 6 months after the intervention. Participants were divided into two groups, Control Group (CG) and Intervention Group (IG), according to their age, gender and body mass index percentages (Table 1.)

Table 1. Participants were divided into two groups Control Group (CG) and Intervention Group (IG).

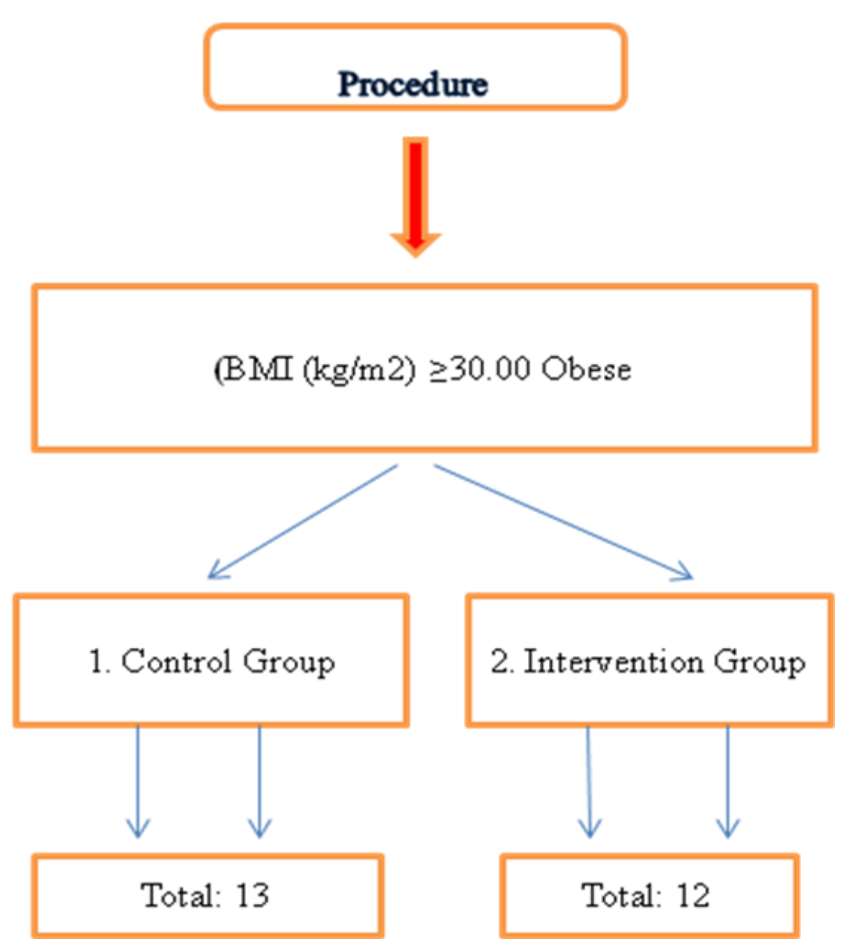




\section{Data Collection Tools}

\section{Exercise Change Processes Scale (ECPS)}

This scale, which was developed by Marcus et al., (1992) Consists of 28 items. The status of individuals in each scale is determined by using the 5-point Likert scale. How often an individual does of exercise under the conditions specified in each item is determined by a grading score ranging from 1 to 5 . The interviewee is asked to read the items of this scale and to select and mark the most suitable for each item among the "never", "rarely", "occasional", "often", "repetitively" options. The scale is evaluated according to the mean score obtained from the item mean scores of all subscales. There are a total of 10 processes in two groups. These processes are summarized below (Transtheoretical Model, 2006).

\section{Group - Experiential Processes}

1. Increase in the level of consciousness; $(1,2,3$ substance ).
2.Dramatic aid / emotional animation; (4,5,6 substance).

3. Re-evaluation of the environment; ( 7 and 8 substance).

4. Self-evaluation; ( $9,10,11$ substance).

5. Social freedom / liberty; (12,13,14 substance of the scale).

\section{Group - Behavioral Processes}

6. In contrast / opposite situation $(15,16,17$ substance).

7. Helper relationships; (18,19 substance ).

8. Strengthening management; $(20,21,22$ substance).

9. Self-liberation; $(23,24,25$ substance $)$.

10. Stimulant control; (substance 26, 27 and 28)

\section{Statistical Analysis}

All statistical analyzes were performed with SPSS version 20.0. $\mathrm{P}$ value of less than 0.05 was considered significant. Differences between control and intervention groups pretest and posttest were analyzed by $\mathrm{T}$ test.

\section{RESULTS}

The findings of this study are presented in Tables 2, 3, 4 and 5.

Table 2. Comparison of Pretest and Posttest Measurements of Physical Properties of Control Group

\begin{tabular}{|c|c|c|c|c|c|c|c|}
\hline Variables & Tests & $\mathbf{N}$ & & Mean & $\begin{array}{c}\text { Std. } \\
\text { Deviation }\end{array}$ & t-value & sd \\
\hline \multirow{2}{*}{ Age } & Pretest & 13 & 68,92 & 3,25 & \multirow{2}{*}{,000 } & \multirow{2}{*}{24} & \multirow{2}{*}{1,000} \\
\hline & Posttest & 13 & 68,92 & 3,25 & & & \\
\hline \multirow[b]{2}{*}{ Height $(\mathrm{cm})$} & Pretest & 13 & 164,92 & 3,04 & \multirow[b]{2}{*}{, 000} & \multirow[b]{2}{*}{24} & \multirow[b]{2}{*}{1,000} \\
\hline & Posttest & 13 & 164,92 & 3,04 & & & \\
\hline \multirow[b]{2}{*}{ Weight (kg) } & Pretest & 13 & 82,85 & 2,54 & \multirow[b]{2}{*}{,229 } & \multirow[b]{2}{*}{24} & \multirow[b]{2}{*}{,821 } \\
\hline & Posttest & 13 & 82,62 & 2,60 & & & \\
\hline \multirow{2}{*}{ BMI } & Pretest & 13 & 30,46 & 0,36 & \multirow{2}{*}{, 560} & \multirow{2}{*}{24} & \multirow{2}{*}{, 581} \\
\hline & Posttest & 13 & 30,37 & 0,42 & & & \\
\hline
\end{tabular}

BMI: Body mass index 
Table 3. Comparison of Pretest and Posttest Measurements of Physical Properties of Intervention Group

\begin{tabular}{|c|c|c|c|c|c|c|c|}
\hline Variables & Tests & $\mathbf{N}$ & & Mean & $\begin{array}{l}\text { Std. } \\
\text { Deviation }\end{array}$ & t-value & sd \\
\hline \multirow{2}{*}{ Age } & Pretest & 12 & 68,83 & 3,41 & \multirow{2}{*}{,- 000} & \multirow{2}{*}{22} & \multirow{2}{*}{1,000} \\
\hline & Posttest & 12 & 68,83 & 3,41 & & & \\
\hline \multirow[b]{2}{*}{ Height $(\mathrm{cm})$} & Pretest & 12 & 166,42 & 3,78 & \multirow[b]{2}{*}{, 000} & \multirow[b]{2}{*}{22} & \multirow[b]{2}{*}{1,000} \\
\hline & Posttest & 12 & 166,42 & 3,78 & & & \\
\hline \multirow[b]{2}{*}{ Weight (kg) } & Pretest & 12 & 84,08 & 3,45 & \multirow[b]{2}{*}{4,489} & \multirow[b]{2}{*}{22} & \multirow[b]{2}{*}{, $000 * *$} \\
\hline & Posttest & 12 & 77,50 & 3,73 & & & \\
\hline \multirow{2}{*}{ BMI } & Pretest & 12 & 30,36 & 0,44 & \multirow{2}{*}{$-10,602$} & \multirow{2}{*}{22} & \multirow{2}{*}{, $000 * *$} \\
\hline & Posttest & 12 & 26,37 & 0,64 & & & \\
\hline
\end{tabular}

BMI: Body mass index

Table 4. Comparison of Pre-test and Posttest Measurements of Control Group Exercise Change Process Scale Sub-Dimensions

\begin{tabular}{|c|c|c|c|c|c|c|c|}
\hline Sub-Dimensions & Tests & $\mathbf{N}$ & Mean & Deviation & t-value & sd & Sig. \\
\hline \multirow{2}{*}{ Increase in the level of consciousness } & Pretest & 13 & 6,46 & 0,88 & \multirow{2}{*}{$-2,115$} & \multirow{2}{*}{24} & \multirow{2}{*}{, $045^{*}$} \\
\hline & Posttest & 13 & 7,54 & 1,61 & & & \\
\hline \multirow[b]{2}{*}{ Dramatic aid / emotional animation } & Pretest & 13 & 6,92 & 1,26 & \multirow[b]{2}{*}{,- 989} & \multirow[b]{2}{*}{24} & \multirow[b]{2}{*}{,333 } \\
\hline & Posttest & 13 & 7,38 & 1,12 & & & \\
\hline \multirow{2}{*}{ Re-evaluation of the environment } & Pretest & 13 & 5,54 & 0,97 & \multirow{2}{*}{,-- 392} & \multirow{2}{*}{24} & \multirow{2}{*}{,698 } \\
\hline & Posttest & 13 & 5,69 & 1,03 & & & \\
\hline \multirow{2}{*}{ Self-evaluation } & Pretest & 13 & 10,62 & 1,12 & \multirow{2}{*}{,- 381} & \multirow{2}{*}{24} & \multirow{2}{*}{,706 } \\
\hline & Posttest & 13 & 10,77 & 0,93 & & & \\
\hline \multirow{2}{*}{ Social freedom / liberty } & Pretest & 13 & 8,38 & 1,26 & \multirow{2}{*}{,- 881} & \multirow{2}{*}{24} & \multirow{2}{*}{,387 } \\
\hline & Posttest & 13 & 8,85 & 1,41 & & & \\
\hline \multirow{2}{*}{ In contrast / opposite situation } & Pretest & 13 & 7,85 & 0,80 & \multirow{2}{*}{,- 763} & \multirow{2}{*}{24} & \multirow{2}{*}{,453 } \\
\hline & Posttest & 13 & 8,15 & 1,21 & & & \\
\hline \multirow{2}{*}{ Helper relationships } & Pretest & 13 & 6,38 & 0,65 & \multirow{2}{*}{,- 299} & \multirow{2}{*}{24} & \multirow{2}{*}{, 767} \\
\hline & Posttest & 13 & 6,46 & 0,66 & & & \\
\hline Strengthening management & Pretest & 13 & 10,85 & 0,99 &,- 433 & 24 & ,669 \\
\hline
\end{tabular}


Table 4. Continued

\begin{tabular}{|c|c|c|c|c|c|c|c|}
\hline & Posttest & 13 & 11,00 & 0,82 & & & \\
\hline \multirow{2}{*}{ Self-liberation } & Pretest & 13 & 10,00 & 0,82 & \multirow{2}{*}{,- 000} & \multirow{2}{*}{24} & \multirow{2}{*}{1,000} \\
\hline & Posttest & 13 & 10,00 & 0,91 & & & \\
\hline \multirow{2}{*}{ Stimulant control } & Pretest & 13 & 9,31 & 0,63 & \multirow{2}{*}{,-- 430} & \multirow{2}{*}{24} & \multirow{2}{*}{,671 } \\
\hline & Posttest & 13 & 9,46 & 1,13 & & & \\
\hline \multirow{2}{*}{ Total Score } & Pretest & 13 & 82,31 & 2,43 & \multirow{2}{*}{$-26,172$} & \multirow{2}{*}{24} & \multirow{2}{*}{,637 } \\
\hline & Posttest & 13 & 85,30 & 10,86 & & & \\
\hline
\end{tabular}

Table 5. Comparison of Pre-test and Posttest Measurements of Intervention Group Exercise Change Process Scale Sub-Dimensions

\begin{tabular}{|c|c|c|c|c|c|c|}
\hline Sub-Dimensions & Tests & $\mathbf{N}$ & Mean & Std.Deviation & t-value & sd Sig. \\
\hline \multirow{2}{*}{ Increase in the level of consciousness } & Pretest & 12 & 7,42 & 1,08 & \multirow{2}{*}{$-9,835$} & \multirow{2}{*}{$22,001 * *$} \\
\hline & Posttest & 12 & 11,42 & 0,90 & & \\
\hline \multirow{2}{*}{ Dramatic aid / emotional animation } & Pretest & 12 & 6,92 & 1,24 & \multirow{2}{*}{$-6,661$} & \multirow{2}{*}{$22,000 * *$} \\
\hline & Posttest & 12 & 10,08 & 1,08 & & \\
\hline \multirow{2}{*}{ Re-evaluation of the environment } & Pretest & 12 & 5,25 & 0,62 & \multirow{2}{*}{$-6,280$} & \multirow{2}{*}{$22,000 * *$} \\
\hline & Posttest & 12 & 7,00 & 0,74 & & \\
\hline \multirow{2}{*}{ Self-evaluation } & Pretest & 12 & 10,75 & 1,06 & \multirow{2}{*}{$-2,939$} & \multirow{2}{*}{$22,008 * *$} \\
\hline & Posttest & 12 & 12,08 & 1,16 & & \\
\hline \multirow{2}{*}{ Social freedom / liberty } & Pretest & 12 & 8,58 & 0,90 & \multirow{2}{*}{$-4,918$} & \multirow{2}{*}{$22,000 * *$} \\
\hline & Posttest & 12 & 10,58 & 1,08 & & \\
\hline \multirow{2}{*}{ In contrast / opposite situation } & Pretest & 12 & 8,17 & 0,94 & \multirow{2}{*}{$-3,546$} & \multirow{2}{*}{$22,002 * *$} \\
\hline & Posttest & 12 & 9,50 & 0,90 & & \\
\hline \multirow{2}{*}{ Helper relationships } & Pretest & 12 & 6,58 & 0,79 & \multirow{2}{*}{$-1,113$} & \multirow{2}{*}{22,278} \\
\hline & Posttest & 12 & 6,92 & 0,67 & & \\
\hline \multirow{2}{*}{ Strengthening management } & Pretest & 12 & 10,92 & 0,67 & \multirow{2}{*}{$-2,639$} & \multirow{2}{*}{$22,015^{*}$} \\
\hline & Posttest & 12 & 11,75 & 0,87 & & \\
\hline \multirow{2}{*}{ Self-liberation } & Pretest & 12 & 10,25 & 0,75 & \multirow{2}{*}{$-3,945$} & \multirow{2}{*}{$22,001 * *$} \\
\hline & Posttest & 12 & 11,50 & 0,80 & & \\
\hline \multirow{2}{*}{ Stimulant control } & Pretest & 12 & 9,33 & 0,89 & \multirow{2}{*}{$-5,564$} & \multirow{2}{*}{$22,000 * *$} \\
\hline & Posttest & 12 & 11,17 & 0,72 & & \\
\hline \multirow{2}{*}{ Total Score } & Pretest & 12 & 84,17 & 2,55 & \multirow{2}{*}{$-97,093$} & \multirow{2}{*}{$22,000 * *$} \\
\hline & Posttest & 12 & 102.00 & 2,91 & & \\
\hline
\end{tabular}




\section{DISCUSSION AND CONCLUSION}

Obesity and physical inactivity, defined as the most insidious disease of our time, are an important public health problem (Soyuer, 2008). The process of change in exercise behavior consists of cognitive and behavioral stages. The individual proceeds in the process of behavior change by evaluating himself and the environment. The progress of the individual in the behavior change process is not always correct. In the process of change in behavior and decline in behavior is a situation experienced (Gümüș, 2015; Jeffery et al., 1999). In this study on the effect of exercise behavior change processes in the prevention of obesity in elderly people; when body weight $(\mathrm{kg})$ and BMI score were examined, there was a significant difference between pre-test and post-test total mean scores in favor of intervention group. When the ECPS of the control group are considered, it is seen that there is a meaningful shot at the bir Consciousness Level Kontrol but there is no significant difference in the other subdimensions. While there was no difference in the sadece Helping Relations ECPS dimension of the intervention group in the ECP subscales; significant differences were found in other subdimensions and total score.

It was found in a study (Diehr and Hirsch, 2010) that elderly persons aged 65 years and older had lower mortality risk and fewer risks of hospitalizations if they were physically active than people who remained inactive. Even moderate physical activity has shown to help elderly to retain their ability to do recreational and household activity (Hirsch et al., 2010). Aging leads to a decline is muscle mass which contributes to problems in motor movements. Approximately 12$25 \%$ of men and women 60-65 have reduced grip strength and slower gait, and the number increases to more than $40 \%$ by the age of 80 (Chaudhry et al., 2010) which in turn has an impact on everyday life: for example, in crossing the street quickly at crossings (Andrews et al., 2010)

Annunziato et al. (2009) found that there was a statistically significant difference between the mean scores of exercise change processes scale and nutritional change process scale scores in the individuals who intervened ( $\mathrm{p}<0.01$ ). Bock et al. (2001) found that there was a statistically significant difference between the pre-intervention and all other follow-ups. Dilillo et al. (2003), there was a statistically significant difference between the mean scores of pre and post-exercise exercise change scale scores in intervention group individuals. Johnson et al. (2006) found that the difference between exercise change process subscale mean scores were statistically significant. Rodgers et al. (2001) and Sutton et al. (2003) was found to be statistically significant in the difference between the pre-test and post-test mean scores of the nutritional change processes scale of the individuals in the intervention group.

\section{Conclusion}

In our study high level of motivation and active involvement in the realization of the goals leads to the development of intrinsic control mechanisms. Individuals who are motivated and involved in achieving a given goal utilize anti-temptation strategies. Therefore, sticking to the rules while making changes necessary for losing weight is sufficient to protect against the dangers of contact with high-calorie food. In obesity, it is important to gain healthy life behaviors such as eating behavior, nutrition and activity habits. In this context, obesity targets: Providing weight loss, Protection of the reached weight, It is the use of regulatory mechanisms against obesity and preventing reversals. Prevention of obesity in the elderly The development of health within the scope of ECP aims to make people sufficient to correct and control their own health. Thus, it is an inevitable fact that individuals should develop healthy living awareness, improve their life style, perceive obesity and increase physical activity as their own tasks and consequently apply health protective and developing behaviors by avoiding risky behaviors.

\section{REFERENCES}

Andrews AW, Chinworth SA, Bourassa M, Garvin M, Benton D, Tanner S (2010). Update on distance and velocity requirements for community ambulation. J Geriatr Phys Ther. Jul-Sep; 33(3): 128-134.

Annunziato, R.A,, Timko, C.A., Crerand, C.E., et al. (2009).A randomized trial examining differential meal replacement adherence in a weight loss maintenance program after oneyear follow-up. Eating Behaviors;10(3):17683.

Bock, B.C., Marcus, B.H., Pinto, B.M., et al. (2001). Maintenance of physical activity following an individualized motivationally 
tailored intervention. Ann Behav Med.;23:79-87. Field, C.A., Adinoff, B., Harris, T. R., et al.(2009). Construct, concurrent and predictive validity of the URICA: Data from two multi-site clinical trials. Drug and Alcohol Dependence, 101(1-2), 115-123.

Chaudhry SI, McAvay G, Ning Y, Allore HG, Newman AB and Gill TM (2010). Geriatric Impairments and Disability: The Cardiovascular Health Study. J Am Geriatr Soc. Sep; 58(9): 1686-1692.

Demirci N, Toptas Demirci, Demirci E (2017). The Effect of School-based Exercise Practices of 9-11 Year Old Girls Students on Obesity and Health-related Quality of Life. Universal Journal of Educational Research, 5(8), 1323-1331

Demirci N, Toptas Demirci P (2018). The determination of physical activity, nutrition and self-sufficiency levels of sedanter individuals of fitness club member. Pedagogics, psychology, medicalbiological problems of physical training and sports, 22 (5), 237-245.

Diehr P and Hirsch CH (2010). Health Benefits of Increased Walking for Sedentary, Generally Healthy Older Adults: Using Longitudinal Data to Approximate an Intervention Trial. J Gerontol A BiolSci Med Sci. Sep; 65A(9): 982-989.

Dilillo, V., Siegfried, N. J., West, D. S. (2003). Incorporating motivational interviewing into behavioral obesity treatment. Cognitive and Behavioral Practice, 10, 120-130.

Kalantari N, Mohammadi N.K, Rafieifar S, EiniZinab H, Aminifard A, Malmir H, Ashoori N, Abdi S, Gholamalizadeh M, Doaei S (2017). Indicator for success of obesity reduction programs in adolescents: Body composition or body mass index? Evaluating a school-based health promotion project after 12 weeks of intervention. Int. J. Prev. Med., 8,73 .

Hirsch $\mathrm{CH}$, Diehr P, Newman AB, Gerrior SA, Pratt C, Lebowitz MD and Jackson SA (2010). Physical Activity and Years of Healthy Life in Older Adults: Results From the Cardiovascular Health Study. J Aging Phys Act. Jul; 18(3): 313-334.

Hedley, AA, Ogden, C. L., Johnson, C. L., et al. (2004). Prevalence of overweight and obesity among U.S. children, adolescents, and adults, 1999-2002. Journal of the American Medical Association, 291(23), 2847-2850.

Jeffery, R.W., French, S.A., Rothman, A.J. (1999). Stage of change as a predictor of success in weight control in adult women. Health Psychology;18(5):543-6.

Johnson, S.S., Driskell, M.M., Johnson, J.L et al. (2006). Transtheoretical model intervention for adherence to lipid-lowering drugs. Disease Management 2006;9(2):102-14.

Johnson, S.S., Paiva, A.L., Cummins, C.O. et al. (2008). Transtheoretical model-based multiple behavior intervention for weight management: effectiveness on a population basis. Preventive Medicine;46(3): 238-46.

Lee, E.B.; Mattson, M.P. (2014). The neuropathology of obesity: Insights from human disease. Acta Neuropathol, 127, 328.

Mastellos N, Gunn LH, Felix LM, Car J, Majeed A. (2014). Transtheoreticalmodel stages of change for dietary and physical exercisemodification inweight lossmanagement for overweight and obese adults. Cochrane Database of Systematic Reviews, (2): 1-75.

Myint, P.K.; Luben, R.N.;Wareham, N.J.; Bingham, S.A.; Khaw, K.-T. (2009). Combined effect of health behaviours and risk of first ever stroke in 20,040 men and women over 11 years' follow-up in Norfolk cohort of European Prospective Investigation of Cancer (EPIC Norfolk): Prospective population study. BMJ, 338, b349.

Obara-Gołebiowska M, Brycz H, Lipowska M and Lipowski M (2018). The Role of Motivation to Reduce Obesity among Elderly People: Response to Priming Temptation in Obese Individuals Int. J. Environ. Res. Public Health, 15(244); 1-13.

Potes, Y.; de Luxán-Delgado, B.; RodriguezGonzález, S.; Coto-Montes, A.; Guimarães, M.R.M.; Vega-Naredo, I.; Solano, J.J.; Fernández-Fernández, M.; Bermúdez, M.; Boga, J.A. (2017). Overweight in elderly people induces impaired autophagy in skeletal muscle. Free Radic. Biol. Med. 110, 31-41. 
Redding, C.A., Rossi, J.S, Rossi, S.R., et al. (2000). Health behavior models. The International Electronic Journal of Health Education, 3, 180-193.

Rodgers, W. M., Courneya, K. S., Bayduza, A. L. (2001). Examination of the transtheoretical model and exercise in 3 populations. American Journal of Health Behavior, 25, 33-41.

Shaheen M, Puri S, Tandon N (2016). Physical Activity Measurement in Elderly: The Indian Scenario. Journal of Physical Activity Research, 1(1); 9-14.

Soyuer F, Soyuer A. (2008). Yaşl1lık ve fiziksel aktivite. İnönü Üniversitesi Tıp Fakültesi Dergisi ; 15(3): 219-24.

Yu Z, Han S, Cao X, Zhu C, Wang X, Guo X (2012). Genetic polymorphisms in adipokine genes and the risk of obesity: A systematic review and meta-analysis. Obesity, 20, 396406. 